\title{
STUDIES ON THE IMMUNITY OF THE EXPERIMENTAL TYPHOID
}

\section{A REVIEW OF EXPERIMENTS GARRIED OUT IN OUR LABORATORY DURING. THE PAST TWENTY YEARS}

\author{
ROKUZO KOBAYASHI* and DAIZO USHIBA* \\ Department of Bacteriology, School of Medicine, \\ Keio University
}

\section{INTRODUCTION}

Although the immunological studies on typhoid and paratyphoid diseases of man have made a progress in its practical field, we cannot help recognizing that there are many problems still remained unsolved in its theoretical field. It seems to us rather strange to see a somewhat chaotic situation in this respect inspite of the remarkable advances in the science of immunology and bacteriology. For the purpose of contributing some fundamental data to clarify this problem, we have being interested in study of the experimental typhoid with laboratory animals for the last twenty years. Since; however, we had no opportunity to report our studies in English language in the past, it is the main purpose of this article to introduce the outline in brief of our experimental methods and results, making our greatest effort in citing many literatures published by our colleagues on this theme. Since most of these literatures were written in Japanese, their titles were translated in English (see References) for the sake of convenience to know at least the outline of substance. Furthermore, we have not cited any report from outside of our laboratory, because the purpose of this article is to introduce our experiments. For the discussion with results of outside experiments we would like to have an another chance. It should be added, moreover, that we hope to publish the latest experimental data successively in the future.

We believe that the study on this problem involves a basic knowledge on the typhoid immunity as well as that on infection and immunity in general.

\section{GENERAL CONSIDERATIONS}

The projects to be mentioned here will cover only the experimental typhoid resembling closely to human typhoid or paratyphoid diseases in its course and

\footnotetext{
* Professors of Bacteriology.
} 
pathogenesis. It is needless to say that, for example, the infection of mice with S. typhi or paratyphi' A or B is beyond the scope of our investigation, because it gives rise to only the septicemia, not to the typhoid at all.

'General discussions upon the past experimentations in our laboratory have been frequently published by Kobayashi $(1,5,8,10,12,14,16,17)$, who has divided the bacterial infections into four large categories from the viewpoint of their pathogenesis $(11,12,16)$, i.e., (a) toxic diseases which are caused by the bacterial exotoxins; (b) exsudative inflammations; (c) productive inflammations, and (d) septicemias which are further divided into the primary and secondary septicemias. We will explain in some detail the differences between these two septicemias. As it is well known, when a large amount of S. enteritidis or typhi-murium is intraperitoneally inoculated to mice, they will succumb within one or two days presenting septicemic state as in the case of the infection with S. typhi, which we call the "primary" septicemia. If, however, mice are inoculated intraperitoneally or intranasally with a relatively small amount of the former salmonellae the typhoid disease occurs in them and, if the strain used is highly virulent, mice may succumb again to septicemia several days after the inoculation which is called by us the "secondary" septicemia. It is a wellknown fact that the same phenomenon can be noticed in mice inoculated per orally with the same organisms.

Kobayashi has emphasized the necessity of this classification (a-d) of bacterial infections because it can be fully anticipated that the mechanism of immunity against bacterial infections will differ each other among the respective groups. He has thus indicated that the typhoid disease should belong to (c) group together with tuberculosis, brucellosis, tularemia or syphilis, etc., and its immunological aspect sharply differs from that of the other group.

We are not intending here to discuss the questions about the practical side of typhoid immunization in human bodies, though some of them were critisized in former days by Kobayashi $(2-4,6,7,9,13)$. Nevertheless, the present situation in which the standardization of potency of typhoid-paratyphoid vaccines is being carried out by the mouse protection test seems to be greatly contradictory with the theoretical viewpoint. Someya ${ }^{(64)}$ has proved the mouse infection with S. typhi suspended in the mucin is not the typhoid disease either, but so called primary septicemia. 


\section{RELATIONSHIP BETWEEN BACTERIAL AND ANIMAL SPECIES (DEFINITION OF THE EXPERIMENTAL TYPHOID)}

For the purpose of choosing the infection of small animals similar to the human disease, what we think is absolutely necessary to investigate the typhoid immunity, the infection of mice with $S$. enteritidis $(18-24,27,33,40,48,50,52,54,55,68,69)$ or the infection of rabbits with $\mathrm{S}$. cholerae-suis or $\mathrm{S}$. paratyphi $\mathrm{C}^{(30,31,39,42,59,61)}$ have been most of ten selected. Besides these, however, the infections of mice with S. abortus-equi ${ }^{(28,34)}$, S. cholerae-suis ${ }^{(40)}$, S. typhi-murium ${ }^{(56)}$, S. pullorum and gallinarum $^{(26)}$, the infection of rats with $\mathrm{S}$. enteritidis ${ }^{(29,38)}$ or S. paratyphi $\mathrm{C}^{(34)}$ and that of guinea pigs with S. enteritidis ${ }^{(42)}$ were also tried. Throughout these studies we used a criterion to decide whether the infection selected was the true typhoid disease or not by the following methods; (a) by testifying the specific typhoid lesion in organs by the histological examination (b) by knowing the distribution of inoculated organisms in the animal body by every day culture of tail blood as well as of various organs of animals killed with ether narcosis, and (c) by examining animals' symptoms during their lifetime.

By these methods the verification that the infections mentioned above are truly the typhoid disease has been demonstrated in the infection of mice ${ }^{(48,50)}$ and of rabbits $(44,45)$ about the problem concerning the clause (a). Regarding the clause (b) it has been recognized in all experiments that the inoculated organisms first enter into regional lymph glands and then are distributed to all organs through lymph and blood, multiplying especially in the liver and spleen. This phenomenon is observed similarly in all infections by any inoculation method including per oral one. As will be mentioned later, however, the tendency to give rise to the "secondary" septicemia after the course of typhoid varies according to the strains used and animal species.

Symptoms of infected animals (the clause c) can be quite exactly noticed in rabbits with special reference to fever, change of body weight, and so forth. Furthermore, the hemograms during the infection were examined in rabbits or in mice, and their changes resemble fairly well to that of the human typhoid ${ }^{(39,60)}$. It should be emphasized here that all immunization experiments which will be introduced in the following paragraphs have been carried out on the bases of studies mentioned above. 


\section{IMMUNIZATION EXPERIMENTS WITH LIVE AND KILLED VACCINES}

\section{(1) Experimental Methods:}

In most of immunization experiments with the live vaccine of the typhoid infection we have used virulent $S$ form organisms as the reinoculation strain and low virulent $R$ form variants which have no common antigens with the $S$ form in the agglutination test as the immunizing strain. In some experiments, however, the so-called mutabile and its daughter variants $(20,26-28,30,39,56)$ or mucoid variants ${ }^{(23)}$, which have all the same antigenic structure to the $S$ form; were chosen as the immunizing strain. These "mutabile and daughter" variants represent a particular phenomenon of the bacterial variation (Kobayashi 71) which we believe has not been reported by others outside of our laboratory. We have clarified that it is a variation specific to galactose. We believe it differs from Massini's "Bact. coli mutabile"-type variation and wish to propose a name "Mutabile variation ( $\dot{M}$ urase)" after the name of its first investigator (Murase 72).

The killed vaccine has been prepared in most cases as the heat-killed vaccine and, in a part of experiments, as a polysaccharide-like extract and the vaccine killed by freezing and thawing of the $S$ form strain used in the reinoculation $(51,52,54,55)$.

The live vaccine has been usually inoculated once per orally, nasally or by the injection method, whereas the killed vaccine has always been injected many times. The period between the immunization and the reinoculation varies from two to four weeks in experiments with the live vaccine and from seven to ten days after the last immunization with the killed vaccine in most cases.

Besides these active immunizations we have tried the passive immunization with the immune serum ${ }^{(23,24,34,35)}$, and also the parabiosis experiment ${ }^{(38)}$. Moreover, some reinoculations in rabbits were carried out intracutaneously and the skin reaction was carefully observed ${ }^{(42,43,61)}$.

(2) Outline of Results and Criterions of Immunizing Effect:

In a few words, the outline of the results of the immunization experiments can be drawn as follows: while the killed vaccine is effective against the primary and secondary septicemias regardless of the active or passive immunization methods, the typhoid disease itself can be effectively protected only by the pre-inoculation of the live vaccine, not by the killed vaccine. It must be mentioned that the effective factor or factors in the immunization with the live vaccine are not clearly explained by the production or existence of antibodies in the usual serological 
sense, because this effect is most distinctly noticed in animals immunized with the $R$ variant-live vaccine which shares no specific somatic antigen with the reinoculation strain. Furthermore, no passive immunization is recognized as effective in the protection of typhoid at all. For the sake of comprehension we cite Table 1 from Kobayashi(12).

Table. 1

\begin{tabular}{c|c|c|c|}
\hline Vaccines & $\begin{array}{c}\text { Antigens of } \\
\text { the vaccine }\end{array}$ & $\begin{array}{c}\text { Protection } \\
\text { of typhoid }\end{array}$ & $\begin{array}{c}\text { Protection } \\
\text { of septicemia }\end{array}$ \\
\hline Killed vaccine & $\begin{array}{c}\text { Same to the re- } \\
\text { inoculation strain }\end{array}$ & - & + \\
\hline Live vaccine & " & $\begin{array}{c}\text { Different from the } \\
\text { reinoculation strain }\end{array}$ & + \\
\hline
\end{tabular}

As it seems most important to discuss here in regard to the criterions by which we have been led to these conclusions, somewhat detail considerations on this point will be made in the following paragraphs.

(a) Survival or Death of Test Animals:

Although a very clear-cut judgement seems to be obtained if the surviving (or death) rate of test animals is taken as a criterion of the effectiveness, we must emphasize the existence of a misleading point: As mentioned before, there are two extreme instances, in which animals suffering from the typhoid disease all succumb to the secondary septicemia on the one hand, and some of them may survive the typhoid without outcome of the septicemia on the other hand, according to differences of the relation between bacterial and animal species. Broadly speaking, therefore, while it seems reasonable to judge effectiveness of the vaccine with the surviving rate of animals in the former instance, this rate will not necessarily mean the protection of the typhoid in the latter. By experiments carried out in our laboratory it has been repeatedly observed that large number of animals survived when immunized with the live vaccine, whereas all of them dies when immunized with the killed vaccine, in the most cases of the infections of mice with a certain strain of S. enteritidis (e.g., "B" strain), or of rabbits with a certain strain- of S. cholerae-suis (e.g., "17S" strain). These infections represent the instances in which all of the control animals succumb to the secondary septicemia.

A question anticipated bere is why the killed vaccine does not protect the occurrence of the secondary septicemia in this instance, if it is effective against the septice- 
mia as mentioned above? This question has been answered by Kobayashi ${ }^{(11,16)}$. He has discussed that the natural resistance of animals may be so much decreased in the course of severe typhoid of this instance that the killed vaccine becomes no longer effective to protect the secondary septicemia. On the contrary, it will be effective in the instance in which some of the control animals may survive the typhoid disease, because the decrease of the natural resistance caused by the typhoid is not very much severe. This consideration has been proved in infections of mice with S. abortus-equi ${ }^{(28,35,37)}$ and S. typhi-murium ${ }^{(56)}$ and of rats with $\mathrm{S}$. enteritidis ${ }^{(29)}$ in which animals immunized with the killed vaccine survived in a larger number than the controls. It is usual that some of the control animals in these experiments survived recovering from the typhoid.

Here we present Table 2 cited rather schematically from $\mathrm{Ando}^{(33)}$ as a typical example of the immunization experiments in the infection of mice with $\mathrm{S}$. enteritidis ("B" strain), in which "survival and death" has been taken as a criterion of effectiveness. It should be remembered in this experiment that the bacterial dose used in the intraperitoneal inoculation was very large $(0.2 \mathrm{mg})$, enough to kill all the control mice within 24 hours (Group I).

Table. 2

\begin{tabular}{c|l|c}
\hline Groups of mice & Immunizing procedures & Results \\
\hline I & None & Death after 1 day* \\
\hline II & $\begin{array}{l}\text { Killed vaccine of the reinoculation } \\
\text { strain (S) } \\
\text { III }\end{array}$ & Death after 6 days** \\
\hline IV & Kive vaccine of the $R$ variant & Death after 1 day \\
\hline V & II+III & Death after 1 day \\
\hline
\end{tabular}

* Mice dies of the primary septicemia.

** Mice were protected from the primary but died of the secondary septicemia after the typhoid disease.

***' Mice were protected from the primary septicemia as well as the typhoid.

(b) Distribution of the Inoculated Bacilli in the Animal Body:

Being substituted for, or carried out in parallel with, the rather erroneous observation of the surviving rate, distribution of the inoculated bacilli in the im- 
munized and control animals has been examined in many of our experiments by the daily culture of blood and main internal organs, or of peritoneal fluids in some cases, of a large number of animals. We have known that even when animals were effectively protected against the typhoid the inoculated bacilli always enter into the regional lymph glands, then further into the spleen, liver, and so forth, but their multiplication is remarkabily inhibited in these organs as compared with the results of the control animals. In experiments with the killed vaccine, however, the distribution of the bacilli does not differ between the immunized and control animals. Thus, the difference of effect between the live and killed vaccine has been very clearly noticed in regard to the distribution and multiplication of inoculated bacilli $(24,27,31,32,34,40,58,59,61)$.

(c) Histological Findings:

Microscopic findings of histological changes, especially the formation of the so-called typhom in the liver have been regarded as an another important criterion of the judgement ${ }^{(44,45,48,50,56,59)}$. We have found again the ineffectiveness of the killed vaccine in this respect, for it did not prevent the formatnon of the typical typhoid changes, while the slight histological changes produced by the live vaccine were not increased by the reinoculation with a virulent strain. However, there is a considerable difficulty of differentiating the changes induced by the reinoculation from those brought about by the live vaccine. This differentiation seems to be impossible at present from the technical viewpoint.

(d) Symptoms of Animals:

Change of fever, body weight or blood pictures have been easily observed in rabbits $(30,31,39,59,61)$, and even in smaller animals in some cases $(29,56)$.

(3) Some Particular Experiments:

We would like to add here a few experiments carried out in our laboratory by methods different from those mentioned above.

(a) Cross Immunization Between Different Bacterial Species:

Ando et al $^{(37)}$ reported cross immunization of mice with the live and killed vaccinas between S. paratyphi B, S. abortus-equi, S. enteritidis, S. cholerae-suis and S. paratyphi C. They have concluded that the primary septicemia can be protected by formation of the antibody against the $\mathrm{O}$ antigen of the reinoculation strain regardless of the bacterial species, but the typhoid disease can be definitely protected only by the live vaccine of the bacterial species which gives rise to the typhoid of mice regardless of possession of the common antigen. An effective cross 
immunization was observed also in the infection of mice with S. cholerae-suis and S. enteritidis $(32,40)$.

(b) Epidemiological Studies in Animals:

Influences of the live and killed vaccines upon the infection of mice with $\mathrm{S}$. enteritidis was discussed from the viewpoint of the experimental epidemiology by Fukutome $\mathrm{e}^{(47)}$ and $\mathrm{Kan}^{(46)}$. These results have consisted one of the important cornerstones of the consideration discussed up to now. Thus, only the live vaccineimmunization showed a good protection against the epidemic of the mouse typhoid.

(c) Experiments with Bacterial Species other than Salmonellae:

The infections of mice, rabbits and rats with Pasteurella pseudotuberculosis have been studied as an analogy to the mouse typhoid(49,57,62,63,65-67). Result of the immunization experiments with this organism, too, are very much similar to those of the typhoid immunization, contributing to the general conclusion of this $\operatorname{article}^{(12,17)}$.

(4) Complexities of the Live Vaccine Immunization:

It seems to be natural that some complexities have arisen during the course of many studies concerning the live vaccine-immunization of the experimental typhoid. We will discuss some of them briefly.

First of all, we must emphasize that the effect of the live vaccine may be greatly influenced by the strain used. For instance, although it has been usually considered by many colleagues that the more virulent the strain is, or the longer the strain is kept in the body after the immunization, the more remarked is its immunizing power ${ }^{(68,69)}$, Takeshita ${ }^{(39)}$ reported one $\mathrm{R}$ varient strain ("IIIT") of S. choleraesuis which was almost avirulent (no fever nor any symptoms in rabbits) but still has a very strong immunizing power against the infection with a virulent strain.

Secondly, Ushiba and Horie(70) have recently found that the injection route of the live vaccine has a great influence on its effectiveness. Thus, they reported one $\mathbf{R}$ varient strain of $S$. cholerae-suis which has lost almost completely its immunizing power by the intraperitoneal or subcutaneous injections during the storage in laboratory, but still can develop that power if injected intravenously into rabbits, and, at that time, showed an immunizing effect similar to that of the "IIIT" strain." The same relation between the injection route and the immunizing power was observed in the infection of rabbits with Past. pseudotuberculosis ${ }^{(65,67)}$. 


\section{DISCUSSION}

We believe that the focus of discussion about this problem should be in a question whether or not an intrinsic difference exists between the effectiveness of the live and killed vaccines against the exprimental typhoid. Kobayashi $(12,14,17)$ has expressed his opinion that the factor of the live vaccine-immunization should be searched in a changed condition of the harmony (it may be rather well explained by the word "Umstimmung") of the body of animals reacting to the stimulus from outside. Some further explanations must be added in this point. Hori ${ }^{(42,43)}$, Nakai ${ }^{(61)}$ and Ushiba ${ }^{(58,59)}$ have not only clarified that animals immunized with the live vaccine showed their protecting power against the reinfection within a very short time after the immunization, but this power was gradually strengthened as time passed by. Furthermore, Ushiba ${ }^{(59)}$ has discussed the protecting power obtained within a short time, which seems not to differ substancially from that obtained after a long time, in a comparison with Koch's phenomenon in tuberculosis or the infection immunity in syphilis.

Against our conclusion that the killed vaccine does not show the immunizing effect to the typhoid disease itself, many contradictory opinions have arisen in this country up to now. Some of them insisted that there is no fundamental difference of the mechanism between the immunization with the live and killed vaccines, and it is only a question of degree that appears to exist, even the criterion of judgement are based on the histological changes or bacterial distributions. We frankly admitt that it is impossible to find out an absolute difference of the mechanism between the both vaccines on the bases of present knowledge, but we would like to say that the effective factor of the killed vaccine will not be a substance like the somatic antigen, being still unknown, even if it could show more or less immunizing effect against the typhoid itself.

At any rate, there seems to be a fairly definite difference of the effectiveness between the live and killed vaccines. From the other point of view, however, we do not know whether or not the immunity of typhoid may be based on only one factor or many factors simultaneously. We believe that this question has to be elucidated in the future by investigations carried out more substancially on the live and killed vaccines (inclusive of materials extracted from the bacterial cell) respectively. 


\section{SUMMARY}

We have presented here a brief introduction of immunization experiments of the typhoid disease carried out in our laboratory during the past twenty years, and discussed the difference of effectiveness between the live and killed vaccines. We think there are still many unsolvd problems about the infection and immunity of the typhoid which must be studied with a new idea under the cooperation of investigators from many fields of the science.

\section{REFERENCES}

1. Kobayashi, R.: The results of the studies in our institute about the vaccination with live vaccines of Salmonellae. Keio Igaku, 10:2004, 1930. (Japanese)

2. Kobayashi, R.: Informations about the infection and protection of typhoid-paratyphoid diseases. Tokyo Ijishinshi, 2773:968, 1932. (Japanese)

3. Kobayashi, R.: The comparison of the statistical observations of the Metropolitan Police Board with those of Drs. Kawaguchi and Hori about the effectiveness of the typhoid vaccination. Tokyo Ijishinshi, 2785:1614, 1932. (Japanese)

4. Kobayashi, R. and staff members: Discussions on the studies of the mechanism of infection and the method of vaccination with paratyphoid bacilli. Nihon Ijishimpo, 544:171, 1933. (Japanese)

5. Kobayashi, R.: Considerations on the vaccination against the typhoid disease from the view-point of experimental studies. Shinryotaikan, 2(3):1, 1932. (Japanese)

6. Kobayashi, R.: On the judgment of the effect of the typhoid and paratyphoid vaccination in man based on the statistical view-point. Tokyo Ijishinshi, 2834:1486; 2835:1564; 2836:1600; 2837:1644, 1933. (Japanese)

7. Kobayashi, R.: On several important fundamental facts about the epidemiology of typhoid and paratyphoid. Rinsho Igaku, 21(10):1429, 1933. (Japanese)

8. Kobayashi, R.: Immunopathological explanations of the natural recovery and the relapse of typhoid and paratyphoid. Rinsho-no-Nihon, 1(4):520, 1934. (Japanese)

9. Kobayashi, $\mathbf{R}$. and staff members: A critical study of the effectiveness of preventive inoculations with typhoid and paratyphoid vaccines based on statistical data. Kitasato Arch. exp. Med., 12(1):1, 1935. (Japanese)

10. Kobayashi, R.: On the immunity 'of the typhoid disease. Ishii-Kiyo, 1(1):1, 1939. (Japanese)

11. Kobayashi, R.: On the causative bacteria and the pathogenesis of septicemia. Nihon Ijishimpo, 940:3302, 1940. (Japanese)

12. Kobayashi, R.: On the immunity of tuberculosis. Nihon Igaku and Kenko-Hoken, 3215:1; 3216:81; 3217:165; 3218:239, 1941. (Japanesc)

13. Kobayashi, R.: On the vaccination of typhoid and dysentery, with special reference to the historical observation of the development of the vaccination method against typhoid. Gyokei-Eiseikai Zasshi, 16(6):1, 1941. (Japanese)

14. Kobayashi, R.: On the infection with S. typhi and S. paratyphi and the onset and course of typhoid diseases. Nihon Igaku and Kenko-Hoken, 3240:1745; 3241:1803; 3242:1871; 3243:1929, 1941. (Japanese)

15. Kobayashi, R.: On the hitherto published explanations about the acquired immunity against typhoid. Nihon Igaku and Kenko-Hoken, 3260:2853; 3261:2903; 1941. (Japanese)

16. Kobayashi, R.: 'On the primary and secondary septicemias with Salmonellae and on 
the immunity against the both. Nihon Igaku and Kenko-Hoken, 3266:81, 1942. (Japanese)

17. Kobayashi, R.: On the concept of infection and immunity of bacterial diseases. Nihon Igaku, 3361:3; 3362:61, 1944. (Japanese)

18. Habu, H.: On the relationship between the elemental bacteriophage of $S$. enteritidis and the immunogenicity and pathogenicity of this bacillus. Keio Igaku, 9(6):1, 1929. (Japanese)

19. Habu, H., and Kubota, K.: On the effect of per oral vaccination with live vaccines of bacteriophage-resistant strains of $\mathrm{S}$. enteritidis. (I). Keio Igaku, 10(8):1, 1930. (Japanese)

20. Ono, J.: The characters of mutabile variants of $\mathrm{S}$. enteritidis.

(1) On the bateriological and immunological characters. Saikingaku Zasshi, 443:23, 1933. (Japanese)

21. Kubota, K.: On the effect of per oral vaccination with the live vaccine prepared from bacteriophage-resistant strains of S. enteritidis. (II). Saikingaku Zasshi. 444:113, 1933. (Japanese)

22. Kubota, K.: Do. (III). Studics on the mechanism of immunization with the live vaccine. Saikingaku Zasshi, 445:338, 1933. (Japanese)

23. Umehara, K.: On the effect of the vaccination with the live vaccine of mucoid variants of S. enteritidis. Saikingaku Zasshi, 444:134, 1933. (Japanese)

24. Ono, J., and Nishihara, E.: On the infection protecting ability of sera of animals immunized with live and killed vaccines of S. enteritidis. (I). Saikingaku Zasshi, 449:770, 1933. (Japanese)

25. Nakamura, B.: On the symptoms of rabbits infected with $S$. Cholerae-suis and $S$. enteritidis. Saikingaku Zasshi, 450:885, 1933. (Japanese)

26. Ando, $K$ :: On the mutabile variation of $S$. pullorum and $S$. gallinarum and on the infection and protection experiments of mice with these bacilli. Saikingaku Zasshi, 453:1122 1933. (Japanese)

27. Noguchi, K.: On changes of the bacterial number in the peritoneal fluid as standard of judgement of the immunizing effect with live and killed vaccines against the intraperitoneal infection with S. enteritidis. Saikingaku Zasshi, 454:1198, 1933. (Japanese)

28. Ochi, Y.: On the infection and the protection of mice with S. abortus-equi. Saikingaku Zasshi, 455:36, 1934. (Japanese)

29. Noguchi, K.: On the infection of rats with $S$. enteritidis and the immunization with live and killed vaccines against this infection. Saikingaku Zasshi, 455:52, 1934. (Japanese)

30. Kobayashi, E., and Noguchi, K.: On the pathogenicity of S. paratyphi C. and protection experiments of the infection with this bacillus. Saikingaku Zasshi, 456:91, 1934. (Japanese)

31. Ando, K.: On effect of the vaccination with live and killed vaccines against the infection of mice and rabbits with S. cholerae-suis. Saikingaku Zasshi, 456:113, 1934. (Japanese)

32. Ando, K.: The protection experiments of the infection with $S_{4}$ enteritidis carried on in mice immunized with the live vaccine of $S$. cholerae-suis variants. (I). Saikingaku Zasshi, 456:128, 1934. (Japanese)

33. Ando, K.: On effect of immunization with the killed vaccine against the infection of mice with S. enteritidis. Saikingaku Zasshi, 456:132, 1934. (Japanese)

34. Iitani, T.: On the protecting ability of the serum of animals immunized with $S$. paratyph $\mathrm{C}$ against the infection of rats with this bacillus. Saikingaku Zasshi, 458:241, 1934. (Japanese)

35. Umehara, K.: Studies on the passive immunization with the immune serum of $S$. aboruts-equi. Saikingaku Zasshi, 458:267, 1934. (Japanese) 
36. Sudo, S.: Studies on the cross immunization with live vaccines among the infections of S. paratyphi B, S. enteritidis and S. Cholerae-suis Saikingaku Zasshi, 458:303, 19.34. (Japanese)

37. Ando, K., Ochi, Y., and Sudo, S.: On the relationship between the immunization with live and killed vaccines against infections of mice with S. paratyphi B. B: abortus-equi, S. enteritidis, S. cholere-suis and S. paratyphi C. Saikingaku Zasshi, 464:757, 1934. (Japanese)

38. Kamiyama, T.: Studies on the immunization with live vaccines against typhoid diseases: Experiments of the parabiosis. Saikingaku Zasshi, 475:679, 1935. (Japanese)

39. Takeshita, S.: The Infection of rabbits with $\mathrm{S}$. cholerae-suis and S. paratyphi $\mathrm{C}$ and the clinical judgement of infection protecting effect of the immunization with live and killed vaccines of these strains. Saikingaku Zasshi, 477:823, 1935. (Japanese)

40. Ando, K.: 1 Observation of the multiplication of bacilli used for immunization and reinfection in organs of mice immunized with the live vaccine of Salmonellac. Saikingaku Zasshi, 478:919, 1935. (Japanese)

41. Takeshita, S.: On the protecting ability of rabbits immunized with the live vaccine of S. enteritidis against the infection with $\mathrm{S}$. cholerac-suis and S. paratyphi C. Saikingaku Zasshi; 481:171, 1936. (Japanese)

42. Hori, D.: On the skin reaction of guinea pigs with S. enteritidis. (I). Saikingaku Zasshi, 481:179, 1936. (Japanese)

43. Hori, D.: On the skin reaction of rabbits with paratyphoid bacilli. (II). Saikingaku Zasshi, 483:313, 1936. (Japanese)

44. Nakanishi, R., and Takeshita, S.: Pathohistological findings on the infection of rabbits with $S$. cholerae-suis and $S$. paratyphi $C$ with special reference to the effect of immunization with live and killed vaccines on this infection. (I). Saikingaku Zasshi, 485:433, 1936. (Japanese)

45. Nakanishi, R,, and Takeshita, S.: Do. (II). Saikingaku Zasshi, 485:449, 1936. (Japanese)

46. Kan, Y.: An explosive epidemie of S. enteritidis which broke out accidentally in mice immunized with the killed vaccine. Saikingaku Zasshi, 486:495, 1936. (Japanese)

47. Fukutome, I.: Studiesion the experimental epidemiology of the mouse typhoid. II. Observation of the preventive effect of immunization. Saikingaku Zasshi, 486:502, 1936. (Japanese)

48. Momose, E.: Histological findings about the infection of mice with S. enteritidis and the effect of immunization with the live vaccine against this infection. Saikingaku Zasshi, 492:61, 1937. (Japanese)

49. Ikegai, R.: A variant strain of Pastcurella pseudotuberculosis rodentium (Pfeiffer) and its protecting power against the infection of mice with the original strain. Saikingaku Zasshi, 495:341, 1937. (Japanese)

50. Momose, E.: On effectiveness of immunization with the live vaccine from the view-point of histological findings of mice infected with $\mathrm{S}$. enteritidis and of bacterial multiplication in the animal bodies. Saikingaku Zasshi, 501:685, 1937. (Japanese)-

51. Ikawa, K.: On the Vi-antigen of S. typhi. (I). Saikingaku Zasshi, 496; 367, 1937. (Japanese)

52. Ikawa, $\mathbf{K}$.: On a bacterial substance of $\mathbf{S}$. enteritidis which is concerned in protection of the mouse typhoid. Saikingaku Zasshi, 506:245, 1938. (Japanese)

53. Sudo, S.: Comparative studies on the protecting ability of rabbits immunized with live and killed vaccines of $\mathrm{S}$. enteritidis against infections with $\mathrm{S}$. paratyphi $\mathrm{C}$ and of S. cholerae-suis variant strains. Saikingaku Zasshi, 509:495, 1938. (Japanese)

54. Ikawa, K.: On immunization with the killed vaccine of S. enteritidis (II). Saikingaku Zasshi, 513:740, 1938. (Japanese)

55. Ikawa, K., and Toda, O.: On immunization of mice with the killed vaccine and combined immunization with killed and. live vaccines of $\mathrm{S}$. enteritidis. Saikingaku 
Zasshi, 514:801, 1938. (Japanese)

56. Kurokawa, M.: On the infection of mice with a strain of $S$. typhi-murium and influences of immunization with killed and live vaccines against this infection. Saikingaku Zasshi, 515:34; 516:95, 1939. (Japanese)

57. Someya, A.: Experiments of the infection with B. pseudotuberculosis-muris and of the immunological protection of this infection. Saikingaku Zasshi, 518:208, 1939. (Japanese)

58. Ushiba, D.: Studies on the live vaccine immunization of the experimental typhoid: Observations concerning the period between immunization and re-inoculation. I. Experiments of mice with S. enteritidis. Saikingaku Zasshi, 524:632, 1939. (Japanese)

59. Ushiba, D.: Do. II. Experiments of rabbits with S. scholerae-suis. Saikingaku Zasshi, 537:741, 1940. (Japanese)

60. Fukushima, K.: On variations of the cells in blood and peritioneal fluid of mice infected orally and parentally with S. enteritidis I. Blood cells. Saikingaku Zasshi, 533:426; 534:502, 1940. (Japanese)

61. Nakai, K.: Immunological studies on the intracutaneous infection of rabbits with $S$. cholerae-suis. Saikingaku Zasshi, 538:785, 1940. (Japanese)

62. Kurokawa, M.: Studies on the experimental pseudotuberculosis of mice with B. pseudotuberculosis rodentium (Pfeiffer). III. Experiments on the so-called live vaccineimmunization. Saikingaku Zasshi, 540:182, 1941. (Japanese)

63. Kurokawa, M.: Do. IV. Experiments on the so-called killed viccine-immunization. Saikingaku Zasshi, 542:229, 1941. (Japanese)

64. Someya, O.: On influences of the gastric mucin on bacterial infections. Saikingaku Zasshi, 547:591, 1941. (Japanese)

65. Mikami, K.: On the intracutaneous re-infection of rabbits with Pasteurella pseudotuberculosis-rodentium (Pfeiffer). Saikingaku Zasshi, 548:652, 1941. (Japanese)

66. Mikami, K.: Experiments on the infection and immunity in rats with Pasteurella pseudotuberculosis-rodentium (Preiffer). Saikingaku Zasshi, 565:132, 1943. (Japanese)

67. Mikami, K.: On the per-oral infection of rabbits with Pasteurella pseudotuberculosisrodentium (Pfeiffer). Saikingaku Zasshi, 566:177, 1943. (Japanese)

68. Kasuga, K.: On differences of experimental data in immunizing experiments of mice with killed and live (S form) vaccines of $\mathrm{S}$. enteritidis. Nihon Saikingaku Zasshi, 3(1):17, 1948. (Japanese)

69. Tominaga, Y.: Intravenous immunization of mice with the killed vaccine of $\mathrm{S}$. enteritidis. Nihon Saikingaku Zasshi, 3(1):18, 1948. (Japanese)

70. Ushiba, D., and Horie, K.: Further findings about the live vaccine-immunization of the experimental typhiod in rabbits. Nihon Saikingaku Zasshi, 3(3):77, 1948. (Japanese)

71. Kobayashi, R.: On the variations of the mutabile type of the colon, typhoid, paratyphoid and dysentery group. Kitasato Arch. exp. Med., 17(2):127, 1940.

72. Murase, W.: On the "mutabile variation" of E. coli. Saikingaku Zasshi, 440:975, 1932 (Japanese) 